\title{
Learning in International Governmental Organizations
}

\section{The Case of Social Protection}

Duina, Francesco; Nedergaard, Peter

Published in:

Global Social Policy

DOI:

$10.1177 / 1468018110366617$

Publication date:

2010

Document version

Early version, also known as pre-print

Citation for published version (APA):

Duina, F., \& Nedergaard, P. (2010). Learning in International Governmental Organizations: The Case of Social Protection. Global Social Policy, 10(2), 193-217. https://doi.org/10.1177/1468018110366617 


\title{
Learning in International Governmental Organizations
}

\author{
The Case of Social Protection
}

\author{
FRANCESCO DUINA \\ Bates College, USA \\ PETER NEDERGAARD \\ University of Copenhagen, Denmark
}

ABSTRACT There exists considerable research on how national policy makers learn from abroad. A significant amount examines the processes and actors at work at the international level. In that strand, relatively little attention has gone to international governmental organizations (IGOs), aside from the European Union (EU)'s Open Method of Coordination. In this article, we carry out a comparative study of learning in three IGOs: the EU, the Organisation for Economic Co-operation and Development, and the Nordic Council of Ministers. Our policy area is social protection. We investigate what is being learned, and the factors that promote or block learning. Our methodology involves an analysis of the formal design of those IGOs and face-to-face interviews with high-ranking bureaucrats from each organization. We observe, first, that the most important learning in IGOs concerns matters that are not part of formal agendas - governance and epistemic issues above all. Second, we see that very different factors promote or block learning in different organizations. We reflect on the implications of these findings for both theory and practice.

KEYWORDS epistemic communities, governance, international governmental organizations, policy learning, social protection

\section{Introduction}

Globalization entails, among other things, increases in the information that flows across nation states (Hopper, 2007; Tomlinson, 1999). This has helped

Global Social Policy Copyright (C) The Author(s), 2010. Reprints and permissions: http://www.sagepub.co.uk/journalsPermissions.nav 1468-0181 vol. 10(2): pp 193-217; 366617; DOI:10.1177/1468018110366617 http://gsp.sagepub.com 
national policy makers in any one country learn about how their counterparts elsewhere approach problems and formulate solutions (Dolowitz and Marsh, 1996; Dolowitz and Marsh, 2000: 6-7; Stone, 2002). Research on learning from abroad has accordingly burgeoned. A good amount has focused on those national-level factors that promote the adoption of policy concepts from the outside. A second major strand has concerned the international arena, with special attention going to the impact of expert networks, non-governmental organizations (NGOs), and pressures stemming from participation in the global economy.

Much less has been said, however, about international governmental organizations (IGOs). Scholars developed considerable insights in the 1960s (Martin and Simmons, 1998). But today most of the attention is focused on one case the European Union (EU)'s Open Method of Coordination (OMC) - with the Organization for Economic Co-operation and Development (OECD) and the World Bank only very recently coming under serious scrutiny. This is surprising: many IGOs involve senior policy makers from the member states and are explicitly designed to promote learning. We should know more about learning in those organizations. Two questions in particular require exploration: what do the member states learn when they participate in IGOs? And what factors promote or block that learning?

In this article, we investigate those questions in three very different IGOs in the area of social protection: the EU (and the OMC in particular), the OECD, and the Nordic Council of Ministers (NCM). All three organizations have units active in social protection. We examine first the formal design of those organizations. We then present data from several intensive, semi-structured interviews with high-ranking bureaucrats in the three IGOs. Existing studies of IGOs rely almost inevitably on the perceptions and reports of national policy makers, or evidence of convergence in national policies. They also focus primarily on policy content. We believe that the institutional positions and tenure of senior bureaucrats can provide us with great insights into the learning process, especially when it comes to issues beyond policy content.

The findings are intriguing. As to 'what' is being learned, the formal design of the three IGOs places, as one might expect, an emphasis on learning about the content of social protection policy and suggests that structured exchanges of information lead to significant learning. However, in line with organizational theories of 'decoupling' (Meyer and Scott, 1983), which emphasize the difference between the formal design and mission of organizations and what actually happens there, our respondents reported otherwise. In their view, the most important learning is around governance (e.g. how to bring about and manage new policies) and unfamiliar epistemes (e.g. alternative ways of understanding and making sense of the world).

As to what factors promote or block learning, the same respondents offered remarkably different perspectives. In the EU's OMC, the proper use of expert 
networks and careful diplomacy before public meetings and the release of official publications are especially important. In the OECD more forceful practices - such as public rankings of countries' policies - are useful. In the NCM, ensuring inclusiveness and exposure to the rigors of global competition are especially important. As a whole, these answers confirm constructivist, coercive, facilitation-oriented, and competition-centered theories of policy learning (Dobbin et al., 2007).

This article is organized as follows. We begin by discussing what we currently know about nation states learning from abroad. We then introduce our three case studies - the EU, OECD, and NCM - and their formal missions in the area of social protection. We follow by presenting the findings from our in-depth interviews. In the conclusion, we reflect on the theoretical and practical implications of our findings.

\section{Learning from Abroad: What Do We Know?}

Nation states learn from beyond their borders. The improvement and refinement of national policies in a variety of areas - from social policy to science, technology, economics, and beyond - partly depends on it (Stone, 1999: 53). Researchers have accordingly spent considerable time discovering what promotes such learning and, to a lesser extent, what is actually being learned. Their findings are captured under various headings besides policy learning, such as policy transfer, policy diffusion, lesson-drawing, and even institutional transplantation and policy bandwagoning (Dobbin et al., 2007; Stone, 1999). Scholars have focused on either the 'domestic' or 'international' variables affecting learning (De Jong and Edelenbos, 2007: 690; Stone, 1999: 52). We examine both strands here.

\section{DOMESTIC LEVEL}

The earliest works on policy learning were concerned with the domestic context. Learning was seen as a rather insulated affair, with the debate focusing on the role of political elites, the structure of the state, the media, and political parties (Hall, 1993; Oliver and Pemberton, 2004). But learning can of course happen in response to data and information that come from outside a country. Much recent research has focused on those domestic factors that facilitate and shape the absorption of such data and information.

Evidence suggests, for instance, that political parties are acutely aware of the ideologies and programs of their counterparts in other countries. When convenient and appropriate, they borrow insights for the purposes of domestic policy making. This seems to have happened most clearly in Central and Eastern Europe, where communist successor parties have carefully studied the social-democratic parties of Western European countries for insights (Hough, 2005; Paterson and Sloam, 2005: 42). 
Networks of experts in a given country have also played a major role in learning from abroad. Situated in academic institutions, think tanks, consulting organizations, and other settings, these experts are 'plugged' into, and also shape, international epistemic communities. They are then able to translate for domestic consumption foreign ideas and information. The transfer is often rather informal and can even occur across policy sectors - as happened, for instance, in Great Britain when the government introduced evidencebased practice in the education field in the 1990s following principles found in Canada's medical community (Hulme, 2006).

Many other variables play a role. These include national political culture, business-state relations (Grüning et al., 2008), the choice of policy instruments (Howlett and Ramesh, 1993), knowledge resources (databases, reports, experts, etc.) (Biegelbauer, 2007), and the presence and activities of think tanks and other institutions (Stone, 2002). We could discuss all of these at length. But we can easily see the merits of these sorts of works: they help us understand the permeability of nation states, the multiplicity of venues through which outside data and information can shape policy making, and the international dimensions of domestic policies.

We can also see, however, their limitations. Nation states are not only 'open' to the outside world but also heavily influenced by outside agents and processes. A proper understanding of learning from abroad requires an understanding of those forces.

\section{INTERNATIONAL LEVEL}

Scholars now recognize that a number of factors operating at the international level shape what and how nation states learn from outside their confines. Most of the attention has gone to those factors which influence or put pressure on but do not rely on the direct participation of - national policy makers.

We know, for instance, quite a bit about how international non-governmental organizations (INGOs) contribute to learning. INGOs are typically highly organized and normative in their stance. They have resources, power, and agenda. As such, they shape learning in a variety of ways, ranging from the distribution of useful data to public shaming, lobbying, funding, consulting, and the articulation of a global discourse on key issues. They often turn to governments directly, but they also reach other INGOs, IGOs, and private and public organizations (Christensen, 2006; Gordenker and Weiss, 1996: 17-18). Examples include Amnesty International, Greenpeace, and the International Planned Parenthood Federation.

International networks of experts also play a major role in the learning process. Far less institutionalized and programmatic than INGOs, these networks typically involve informal or semi-formal connections among individuals with extensive knowledge of particular issue areas. They provide national policy makers with qualified, technical, and supposedly unbiased data 
about policy issues, indicators, and solutions. And they actively shape discourses around key policy topics (De Jong and Edelenbos, 2007; Haas, 1992: 2; Stone, 2004; Yeates 2008).

There are then more systemic-level variables influencing national policy makers. Perhaps the most important is the global economy and the 'lessons' that can be learned by way of exposure to competition and the international marketplace, comparative data on performance, and increased external scrutiny (Meissner, 2002; Sinn and Ochel, 2003).

All of these works help us see that international forces shape how nations learn from abroad. But they share one limitation: a view of national policy makers as domestically situated 'targets' of foreign pressure or 'recipients' of data and information from the outside. In reality matters are quite different. Policy makers participate directly in international forums and spaces. The most obvious and possibly important are IGOs. Many IGOs are forums for bargaining, negotiations, and policy making. Some are at least explicitly designed to encourage learning. Most, if not all, contribute to learning in some form or another (Checkel, 2005). As observed by perhaps the two most prominent theorists of policy learning, 'international governing organizations (IGOs), such as the OECD, G-7, IMF and the UN and its various agencies, are increasingly playing a role in the spread of ideas, programs and institutions around the globe' (Dolowitz and Marsh, 2000: 11). What do we know, then, about policy learning in IGOs?

Research on the EU and, in particular, the $\mathrm{OMC}$ has been significant. The OMC is a non-compulsory process launched in the 1990s where, with the help of the European Commission especially, member states share domestic experiences in selected policy areas, agree to adopt certain indicators and language for measurements and policy making, showcase their accomplishments, and more. Some researchers believe little learning happens in the OMC (Hatzopoulos, 2007). But many argue otherwise pointing as evidence to national reports, the evolution of particular policies, the modus operandi of the OMC, and interviews with national officials (Zeitlin and Pochet, 2005).

We know comparatively less, instead, about learning in other IGOs. If we turn to one of the most established learning-oriented IGO - the OECD - we find that most of the attention has gone to the organization's ability to impose on the member states its vision of the world (Armingeon and Beyeler, 2003; Lehtonen, 2007). Most analysts reach the conclusion that countries ignore the OECD's recommendations (Lehtomen, 2007; Peters, 1997). A similar preoccupation with power informs a recent wave of analyses of the IMF, the World Bank, and the United Nations (Barnett and Finnemore, 2004; Vetterlein, 2007; Woods, 2006). But imposition is not the same thing as learning. At best, it can lead to learning. The same can be said of 'socialization' - another topic of recent research on IGOs (Johnston, 2008; Lewis, 2005). 
The few, though increasing, studies that do focus on learning in IGOs have important limitations. Some simply report that little useful learning is taking place (Schäfer, 2006). Others disagree (Studlar, 2006). However, their emphasis is on policy content above all: on the policy ideas that nation states may or may not find useful when devising domestic policies (Deacon 2007; Mahon and McBride 2008; Orenstein 2008; Yeates 2008). Learning, of course, is about policy content but also much else. These studies say little about what, besides content, national policy makers may be learning from each other, and what, exactly, may be promoting or blocking such learning.

Third, and crucially, most of these works rely for evidence on interviews with national representatives, published national or IGOs' reports, and data on policy convergence across countries. ${ }^{1}$ This is sound methodological practice. Yet, it leaves out of the picture some of the most valuable sources of insights: senior IGO officials in charge of policy units designed to encourage information and data sharing across nation states. These officials enjoy a privileged perspective: they normally have far more years of experience than national representatives, are expected to promote learning rather than advance a particular national view, and have a holistic view of their organization.

The conclusion is clear: we still know quite little about the learning that is happening in IGOs, despite the fact that this is where national policy makers come into direct contact with each other. In the next section, we address this problem by turning to the case of social protection in three IGOs.

\section{Learning about Social Protection in the EU, OECD, and NCM}

The number of IGOs - now well over 1000 - has grown steadily since the end of World War II. The increase is all the more impressive when we observe that many IGOs have actually vanished in that same time period (Shanks et al., 1996). In the following pages, we investigate learning about social protection in the EU's OMC, the OECD, and the NCM. In line with recent methodological discussions about case studies selection in the social sciences (Bennett and Elman, 2007; Gerring, 2004; Odell, 2004), we chose these three IGOs for two reasons. All three organizations are explicitly designed to promote learning across the member states in important policy areas. If any learning happens in IGOs, this is where we are most likely to find it and subject it to analysis. These are, then, three 'intrinsically important' case studies (Odell, 2004). Second, as Table 1 shows, the three organizations differ from each other in terms of size, age, homogeneity of membership, and objectives. This diversity which follows 'the method of difference' logic - will ensure that our findings have more relevance than if we selected very similar organizations.

We turned to social protection. All three organizations have units dedicated to learning in that policy area. Yet, even in the case of the OMC, we know 
TABLE I EU, OECD, and NCM: Basic differences

\begin{tabular}{|c|c|c|c|c|}
\hline$I G O$ & Size & Year founded & Homogeneity & Objectives \\
\hline EU (OMC) & 27 & 1997 & $\begin{array}{l}\text { Mixed: all } 27 \mathrm{EU} \\
\text { member states }\end{array}$ & $\begin{array}{l}\text { Convergence of policies } \\
\text { toward best practice } \\
\text { among the member states } \\
\text { in various policy areas }\end{array}$ \\
\hline OECD & 30 & 1961 & $\begin{array}{l}\text { Low: Countries as } \\
\text { different as the } \\
\text { United States, } \\
\text { Turkey, and Mexico }\end{array}$ & $\begin{array}{l}\text { Sustainable economic } \\
\text { growth }\end{array}$ \\
\hline $\mathrm{NCM}$ & 5 & 1953 & $\begin{array}{l}\text { High: Denmark, } \\
\text { Finland, Norway, } \\
\text { Sweden, and Iceland }\end{array}$ & $\begin{array}{l}\text { Policy coordination and } \\
\text { adoption of common } \\
\text { stances toward the } \\
\text { external world }\end{array}$ \\
\hline
\end{tabular}

remarkably little about what national representatives are learning. Figure 1 situates those units in their broader institutional context.

We followed a two-step approach in our investigation. First, we examined the formal design of those units. At the official level, what sort of data and information are those units helping national representatives share with each other? And through what means are they trying to achieve this? We answered these questions by examining those units' programs, structures, and outputs.

Our second step was to conduct semi-structured, face-to-face, extended interviews with the leaders of each social policy unit. Learning is a process, and formal analysis of organizations cannot yield much valuable information about what actually happens inside those organizations. In-depth, on the ground qualitative investigations can prove fruitful (Odell, 2004). We approached our
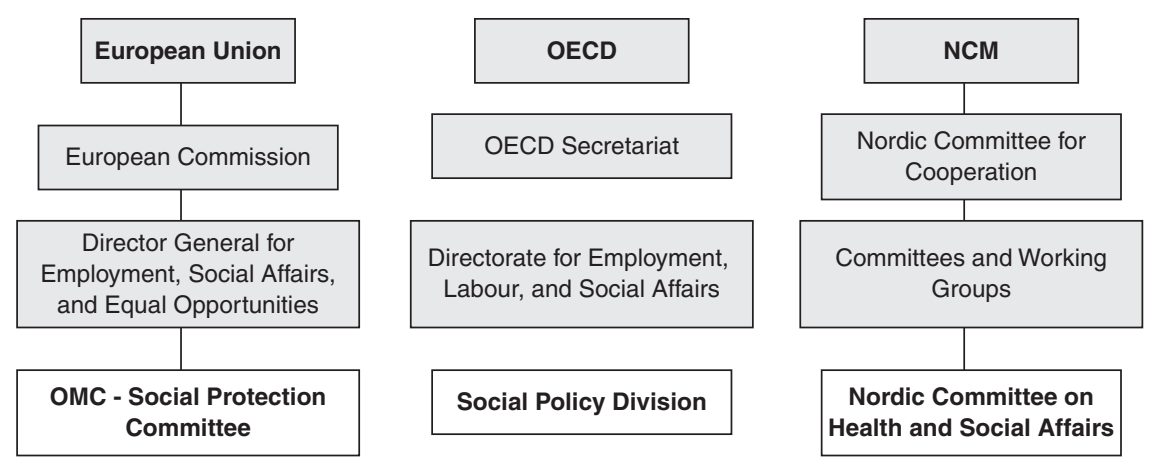

FIGURE I Social protection in the EU, OECD, and NCM 

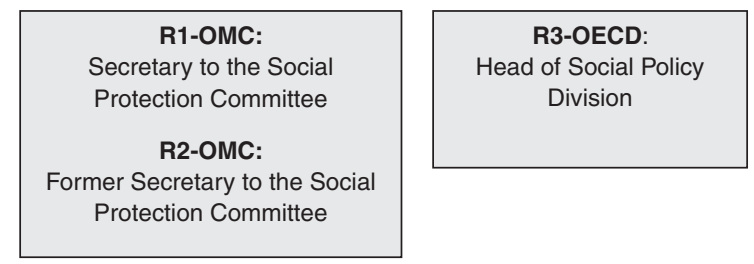

R4-NCM:

Head of the Nordic Committee on Health and Social Affairs

R5-NCM:

Senior Advisor

FIGURE 2 Respondents (R) from the EU, OECD, and NCM

interviewees in 2008 with 14 initial questions, ${ }^{2}$ all of which clustered around what member states learn from participating in each IGO, and what factors seem especially important for, or harmful to, such learning.

In the case of the OMC, we interviewed the former leader of the Social Protection Committee, since he held that job for two years, and the current leader (who was in place for less than two months). In the case of the OECD, we interviewed the longtime head of the Social Policy Division. As for the NCM, we interviewed the head of the Nordic Committee on Health and Social Affairs but also a senior advisor, given her prominent role in the learning process. These were the most senior officials overseeing and managing the everyday operations of those units, enjoying a continuous and long-term exposure to the learning process unmatched by anyone else there. Figure 2 identifies our interviewees.

We report first on the formal design of the social protection units of the OMC, OECD, and NCM.

\section{Formal Design and Learning about Social Protection}

The programs, activities, and outputs of the social protection units of the EU's OMC, OECD, and NCM make one thing clear: learning is about policy content. The units help national officials learn about the laws and administrative programs in place in the various member states. At the same time, there are important differences in the mechanisms used for promoting learning. The OMC and OECD rely extensively on published materials: reports, documents, white papers, presentations, and more. The NCM, by contrast, operates on a more interpersonal level: publications are very few and ad hoc, meetings and conferences are very frequent. Let us consider each unit in turn.

The OMC was born out of the Lisbon process in 1997 and applied originally to employment. It now covers several policy areas where traditional community law cannot be used. Activities in the area of social protection began in 2000, when the Social Protection Committee was created to promote learning on pensions, health care, long-term care, poverty, housing, and more. The goal is to identify best practices. This is done through four institutional 
mechanisms, all of which make heavy use of publications to capture and spread policy content.

Perhaps the most important mechanism involves the writing and dissemination of National Strategic Reports (NSRs) on social protection. Submitted by national representatives every two years, the reports disclose each country's legislative approaches and frameworks, along with its progress towards achieving commonly agreed policy goals in responses to recommendations from the EU. ${ }^{3}$ These are generally rich, detailed, and highly informative documents.

The European Commission and Council, in turn, issue Joint Reports (JRs) where they offer deep analyses of domestic and foreign legislative frameworks, evaluate national approaches, benchmark progress, and recommend good practices. Well-designed laws from across the EU are set against weaker laws. Strategies are examined, problems identified, and solutions suggested. Like NSRs, JRs are made publicly available on the Internet upon publication. ${ }^{4}$

Peer Review Programs constitute a third learning venue. There is less reliance on published materials and much more on live, personal interactions. The focus remains, however, on policy content. The Social Protection Committee selects, in consultation with the member states and the Commission, several countries (eight in 2008, for example) that can boast 'best practices' in a particular issue area and wish to host for a few days representatives of other member states. During the visit, the host country's policies and programs are scrutinized, extended question-and-answer sessions held, and ideas exchanged. Short reports on the visits are made available to the public. ${ }^{5}$

The fourth venue for learning in the OMC is somewhat different from the others (Mabbett, 2007). The European Commission and Council, in collaboration with the member states, produce a list of indicators: statistical tools, ratios, and other numerical and qualitative measurements. The member states are expected to use those indicators when writing their NSRs and reporting on progress towards commonly agreed objectives. Most reporting by the Commission and Council must be done with those indicators in mind. The focus continues to be best practices in policy terms. And the medium of communication is still structured exchanges among the participants and published documents. Yet, indicators are a step removed from content: they have more to do with the development of a common terminology and language. ${ }^{6}$

Like the OMC, the OECD is formally about content. Its Social Policy Division disseminates information about best policies for protecting vulnerable segments of society. In the case of the OECD, however, the ultimate goal is ensuring sustainable, dynamic economic growth. This determines the specific types of policies that come under scrutiny. The promising increases in productivity among vulnerable segments of the population - through higher participation rates in the workforce or training, for instance - are of special interest. Hence, the focus of a major recent report on disabled people was on ways to remove disincentives to work and improve labor market activation (OECD, 2003: 3). 
The Social Policy Division relies heavily on published materials to spread information and data about best practices. In this way, too, it resembles the OMC's Social Protection Committee. The three most important initiatives at the moment - Making Work Pay (aimed at unemployment), pension system monitoring, and the development of useful social indicators - are all centered around publications. ${ }^{7}$ Much the same can be said about past initiatives. Most publications, in turn, have a quantitative flavor, in line with the economic outlook of the organization: tables, rankings, and graphs abound.

The NCM is also content-driven: national officials are encouraged to learn about policies and approaches in place in the member states. Here social protection appears as one of 10 policy areas (the others include fisheries, food, gender, the environment, energy, health, and the labor market). The Council of Ministers for Health and Social Affairs is in charge. ${ }^{8}$ But the goal of the $\mathrm{NCM}$, in social protection and elsewhere, is rather different. Recall that that the OMC and OECD are about best practices. There, hierarchies are established. Some policies are hailed while others are disregarded. By contrast, the NCM is much more about cooperation and coordination - about finding a communal, 'Nordic' approach to problems: what can be done at the regional level to address more effectively issues around pensions, unemployment, or disability? What position should the Nordic countries take in negotiations in international forums such as the EU or the World Health Organization? What is the future of the Nordic model in social protection (Nordic Council of Ministers, 2007)? All this is consistent with a long history of efforts to increase mutual understanding, rather than uniformity, among the Scandinavian countries (Petersen, 2006).

These objectives shape the institutional practices the NCM relies upon at the formal level to foster policy content learning. Substantive publications are ad hoc and typically outsourced to supporting institutions (such as the Nordic Council for Alcohol and Drug Research). 'Discussion papers' rather than topdown reports from senior officials are most common. There are no regular country reports, comparative assessments, or rankings. Much is made of in-person meetings. Biannual conferences among national representatives, coupled with ongoing communication via phone or electronic mail with ministerial delegates, is the preferred method of information and data dissemination.

Our analysis of the formal design of the OMC, OECD, and NCM's social protection units can only yield a partial picture of the actual learning that takes place in everyday life. Much more often happens within and beyond that design. We turned to IGO officials for their insights.

\section{Perspectives of Senior Bureaucrats}

As to 'what' is learned in IGOs about social protection, our interviewees agreed that, while the formal focus is on policy content, the most valuable learning concerns issues not on official agendas. The same interviewees differed 
remarkably when discussing the factors that promote or block learning. We discuss each matter in turn.

\section{WHAT DO THE MEMBER STATES LEARN FROM EACH OTHER?}

Sociologists have argued for quite some time that there exists a difference between the formal rules and objectives governing organizations and everyday reality. They refer to 'decoupling' to describe the way in which everyday activities in an organization depart from the formal structures that are supposed to guide them. The process is often inevitable, as those structures tend to conform to idealized principles of organizational design that cannot ensure efficiency and the fulfillment of actual objectives (Meyer and Rowan, 1991: 57-8).

When it comes to what member states learn in the OMC, OECD, and NCM, our respondents agreed that what is officially discussed in those IGOs - policy content - is important. Yet, all of our respondents made clear that some of the most valuable learning concerns issues and matters that do not figure prominently in the official programs, activities, and outputs of those IGOs. 'The process of mutual learning', R1 from the OMC told us, 'is going on on a daily basis ... even from the capitals ... during the days between one meeting and another'. R2 from the OMC put is as follows: 'after all, we really are a platform ... when we publish a report ... we do it with the purpose of facilitating the exchange between member states. So, if member states take the cue from the report and they pick up the phone and just call their counterparts in another member state ... that is the kind of things we try to make happen' (R2-OMC). $\mathrm{R} 3$ from the OECD explained how 'a lot happens at the edges ... we always make sure we have big coffee breaks. You have some sort of social event at the end; you don't make the meeting last more than, say, six hours a day; absolutely no'. What, then, do the member states learn in those instances and contexts?

They learn about governance. Governance is not about the content of policies but about how to make and then implement those policies. It is the art of getting things done by managing various stakeholders, understanding what can and cannot be accomplished in a given policy and institutional environment, and making effective choices. This is what national representatives are eager to know more about and are in fact learning from each other - but that cannot be easily discussed in open forums. As R2 told us in a statement that undermines the entire formal OMC process, the 'member states do not need to know that the way to deal with a pension crisis is such, such, and such. They have well-informed people in their ministries'. They take something else from the OMC instead:

... the implementing side [of things]: how do you deal with difficulties at various political levels, regional levels ... how do you deal with overlapping authorities? ... How do you deal with your counterparts in the treasury? ... I think that the member states, at least the representatives of member states, I have been in contact with are very much interested in these practical questions - the governance side, if you will. (R2-OMC) 
Member states, R2 continued, wish to gain insights into 'how do you make it happen? I think that is where there is most interest. That is my understanding of the work we did reviewing the OMC last year'. They wish to know how to position policy ideas for public acceptance, overcome skepticism and dissent, and generate positive momentum.

R3 from the OECD echoed this view. As he put it, 'if you ever came to an OECD meeting ... You know we have a great, huge [report] with maybe an hour and a half discussion - an hour and a half sounds quite long - that's 30 countries. I mean none of them are going to say anything very deep'. What they learn, instead, is about subtler and more practical questions: 'did you compensate the losers? Did you package this reform with something else at the same time?' (R3-OECD). Successful policy making requires overcoming opposition, and the OECD affords national representatives with a chance to learn about how that is done.

At the same time, governance is also about knowing what can and cannot be tackled at a particular point in time. It is about timing and deciding that something should and can be done. Thus, in the OECD Social Policy Division at least, member states learn about 'actually getting the confidence to do something, because other countries are doing something'. National representatives learn the limits of the possible, or, as our interviewee put it, 'what can you get away with?' (R3-OECD). Learning, then, is not about content, but about when and how to make choices.

The second major area of learning concerns the articulation and absorption of a language for thinking about the world. Societal problems do not simply exist but require identification and definition. Words help us see the contours and internal qualities of issues and problems. They establish limits and boundaries but also enable us to mobilize against what needs fixing. Learning here concerns the fundamental building blocks behind policies. R3 from the OECD described this process as follows:

What we're doing is find a way to talk about policies using the same terms, creating, using the same forms of analysis, so that people can compare across countries, and building some sort of support network for officials, so that when they do think something is, what the minister's proposing is wrong, that they can actually either ring us up or ring other people, that they know from the OECD to say, what did you do, how did you deal with this? ... I think, when [the academics] start talking about creation of epistemic communities, it rings a bell in this area. (R3-OECD)

$\mathrm{R} 2$ from the OMC had similar reflections:

An episteme ... an epistemic agreement - really in the end we all speak the same language. And that in itself is a very good result ... this is really an epistemic framework that we share. But it's a 'we,' it's not just effort by the Commission, it's also an effort by the Council, you know ... When you ask them [national officials], what do you appreciate about the OMC, it's not the quality of our drafting, of our report or even the structure. It's the fact that it's a permanent dialogue. (R2-OMC) 
NCM officials did not explicitly refer to the formation of epistemic communities. But they certainly depicted their organization as a forum where worldviews are shared and participants' perspectives on issues and problems merge to a degree. As R4 from NCM put it, 'we are kind of a mixed melting pot of all the differences in the different countries'. In the NCM, countries are developing 'like-minded views on ... matters'. They are not learning about policies, but about the ideas behind the policies. This is of course 'not usually on the formal agenda, but it's kind of the informal information that goes on during the meeting or at specific other points in time' (R4-NCM). This is what happened, for instance, during discussions over the launch of a new Nordic institute for bird flu research:

We have over the past couple of years tried to put up or to investigate whether to put up a common Nordic institution on producing vaccine for bird flu. We haven't yet succeeded in doing so, but the ... work or the analyses that have been made in these two years have given [us] a lot of information; a lot of common knowledge ... so even if we haven't succeeded in getting the common facility, we have a lot of learning.

Behind official documents and processes, then, are more fundamental ideas and viewpoints. R2 of the OMC invited us to think of his unit, the Social Protection Committee, as:

... the tip of the iceberg. Think again of the example of [child poverty]. In the [Joint Report] there is maybe two pages on child poverty; there's one key message. That's really the most high level you can get. But in order to have [compelling] messages, ok, it took a couple of meetings, but it also took this huge report by the indicators subgroup. For doing that report they also had to exchange views and to determine what are the best indicators to monitor child poverty ... so there was really a lot of mutual learning, because it was prepared of course by the secretary of the SPC, but with a lot of cooperation from the member states.

Now, a number of factors shape the very nature of these epistemic communities. The very working language of an organization, for instance, is of much importance. For instance, though the official working languages of the OECD are French and English, only the latter is really used:

We are an Anglophone organization. That does limit the reach of our work in particular countries, and it means that we almost rely on the community, the epistemic community, the academics, the government officials to actually sell our work domestically. (R3-OECD)

Similarly, the specific mandate of the organization as well as the extent to which it is able to push member states in new directions greatly influences what frames, terminologies, and ideas national representatives are bound to share. The NCM, for instance, can take significant initiatives: 'our secretary general has the privilege of putting up proposals. So this gives us ... the possibility to take initiatives on our own and to forward them to the ministers or 
the senior official groups' (R4-NCM). The same cannot be said for the $\mathrm{OMC}$ - as R2 put it, 'this is also the EU, so we work together with the member states' - but certainly for the OECD, though here the power of the USA poses certain limits:

[There are] people who want to influence the discussions. So people who want to determine what we work on in a much more vocal way than the other countries. All countries obviously have a vote on what we do, but some will definitely try to take the lead in trying to say that what we should be doing is the following. You know, this is the paradigm we should be pushing.

I mean, if we can ever come to some sort of consensus about wording, that's extremely useful. Now in social policy for the OECD it's much more difficult than at the EU-level, and it's bad enough at the EU-level. But for the OECD we have a large elephant in the room, that goes by the name of the United States, that really makes life difficult for us on social policy. And for the last eight years the view of the United States is that the only social policy worth speaking about was promoting marriage. (R3-OECD)

But variations in what shapes the specific episteme in a given IGO do not alter our overall conclusion. Along with governance, in the minds of those who lead the learning process around social protection in the OMC, OECD, and NCM, the member states learn from each how other to frame, think, and talk about problems and solutions. Learning concerns much less the 'what' and much more the 'how' of policy making.

\section{WHAT FACTORS PROMOTE OR BLOCK LEARNING ACROSS THE}

\section{MEMBER STATES?}

Our respondents were especially interested in discussing the factors that promote or block learning in their organizations. Recent literature suggests that policy makers take in ideas and information from outside in one of four ways (Dobbin et al., 2007; Dolowitz and Marsh, 2000: 11). The first - put forth by constructivists - emphasizes that a few key actors (expert networks above all) operating at the international level generate policy information and data. National policy makers tap into those insights to craft their policies. The second points to coercion: the ability of a few powerful players to have their worldviews imposed on others. Here, member states learn from other member states or other organizations (the IMF, for instance) in forceful fashion.

Competition theorists point out that the rigors of global competition make clear which national policy approaches are the best - i.e. most efficacious. Quality matters more than power, as countries with poor approaches fail and those with good ones succeed. The fourth and last school of thought emphasizes the ease with which policy makers can access each other's policy data and information. Attention goes to those practices, rules, and technological advances which facilitate such access. Table 2 summarizes these four schools of thought: 
TABLE 2 Modes of learning

\begin{tabular}{lll}
\hline School of thought & Key actors & Process \\
\hline Constructivism & $\begin{array}{l}\text { Expert networks, INGOs, } \\
\text { interest groups }\end{array}$ & Collaboration \\
Coercion & Powerful nations, organizations, groups & Imposition \\
Competition & Pressures from global economy & Natural selection \\
Facilitation & International organizations, technology & Openness, access \\
\hline
\end{tabular}

Our interviewees offered answers that supported all four schools of thought. But those answers varied dramatically across the three units. Moreover, they identified a few key factors that defy current theoretical paradigms about learning. We consider each unit in turn.

\section{$O M C$}

$\mathrm{R} 1$ and $\mathrm{R} 2$ from the $\mathrm{OMC}$ identified factors that strongly conform to the constructivist and facilitation perspectives. On the constructivist front, much emphasis was put on the role of national experts in supporting the OMC, where they are made part of 'subgroups'. Experts from the member states help the OMC achieve precision and concreteness - all key ingredients to achieving consensus:

Oh, subgroups are very important. I think ... I'm a big fan, because I think that ... we would like to have the most solid framework ... we are convinced that the more concrete you are the easier it is to have an agreement with the member states. You have to struggle for hours on a political document about adjectives and adverbs. If you involve the real specialists from the member states, we can really have a breakthrough ... [their work] paves the way for political agreement within the committee ... because you have all the steps of the reasoning ... down.

R1 concurred with this stance:

I can confirm, that this [relying on experts] continues to be applied for sure, and there was the launch of a new group, a new subgroup, last month. This is on active inclusion issues. And this is again in order to have an in-depth discussion preparing what will be the position of the SPC. And even in order to better prepare what could be an integrated ... so this is absolutely a way that is used and will be used.

At the same time, on the facilitation side, R1 and R2 openly emphasized that good, impactful policy documents are possible only if potential opposition and problems are resolved before the time of formal meetings and publications. OMC officials can play an enormous role in that regard:

Usually, when I was secretary, I used to call them [the member states] in advance, just to clear things before [the meeting]. I think, it's [a good way] to do it ... To try 
out the ideas, before... Well, because I only have one meeting to get a document adopted for the council. I really need that meeting to be productive. If I have 27 different opinions ... I need to prepare not necessarily the agreement, but some sort of shared understanding must be there from the beginning. Otherwise it would be impossible. It would take forever. (R2-OMC)

The practice makes it possible not only to reach agreement before announcements are made but also avoid embarrassing setbacks afterwards:

But I was not asking their permission, I was simply trying out ideas. How would you react to this, and I was trying to find out, what was their position, and what really do you object to in this commission communication? ... You want to have them engaged. Because nothing is more dangerous, if I can make an example, than having someone shutting up for two meetings, and then coming up ... or after the meeting suddenly realizing what they have approved. (R2-OMC)

R1 and R2 thought little of coercive practices. They pointed out that there is little pressure of consequence coming from the member states:

Of course this is an EU committee, and you can see the traditional clustering of countries around the positions that you would expect. With France, Spain, Italy, Portugal, Austria often on one side. Germany mostly concerned with subsidiarity and the relationship with [the Länder] or things like that. It's just part of everyday politics. But no, at least in my tenure, I did not see any active push by some countries. (R2-OMC)

R2 in turn insisted that the Social Protection Committee itself has little power to force its viewpoints on the member states. 'Everybody enjoys a little power', he said, 'but, no, I'm joking ... I mean, you can force maybe reforms, but as you know, it doesn't work all that well ... What we have in place here is a totally voluntary process'.

Both respondents, finally, shared with us insights that do not neatly 'fit' with the four theories on learning discussed above. The most salient had to do with the mindset of national representatives. R2 spoke of 'conceptual inclination'. Sometimes the member states 'are trying to learn ... and to apply it to their own context'. But in other cases 'member states have a more defensive attitude'.

\section{OECD}

R3 provided us with remarkably different answers. He spoke about forceful ways of ensuring that certain ideas from the member states are adopted or fall out of circulation. 'Countries', he observed, 'normally accept that they want to be steered as well. I mean, this is partly the freedom of the OECD compared to the European Union'. One venue for doing so is shaming by way of ranking countries in terms of performance. This is a delicate process, of course, but one that certainly works: 
The other thing that's always terribly, terribly influential, and therefore used ... are league tables. We are generally ... Well, you have to be careful with them. Clearly, if we use league tables all the time, and say these countries are top, and these countries are bottom, the countries at the bottom are being given a problem that they have to deal with. And as I say, we deal very much with the ministries - for good or ill, that's who we're dealing with - if we start ranking a country to the bottom, we are giving clients a problem. (R3-OECD)

Shaming can push policy leaders to look for inspiration beyond their national borders. At the same time, it can also justify the decision of alreadycommitted leaders to borrow from other countries. Consider this statement: 'a classic example is Germany and family policy. At the moment we can't beat them up enough. The more we are unpleasant and nasty to them about the failure of their family policy the happier they are, because they want change, so they need the publicity' (R3-OECD).

The OECD is forceful in other ways, too. Countries otherwise closed to others' ideas can prove more open if the OECD threatens them with various forms of retaliation. R3 described to us how the conservative Canadian government eventually changed its mind about early retirement schemes:

And there was nothing that the administration, the public officials, who violently opposed to this - I mean they lived through all the problems of the early retirement schemes in the past - that they could do to actually stop the government from being extremely keen on early retirement. In the end, the thing that worked was Canada wanted to host a ministerial meeting on employment, and the officials kept saying to the minister 'you're going to be trying to do something diametrically opposed to what the OECD says, and this is mad. You know, you're going to get some bad press on this'. And the minister backed down for that reason. (R3-OECD)

As to which countries are especially active in pushing for their perspectives to be adopted, R3 had interesting revelations:

The Netherlands used to be very, very active ... at the moment they're less active than they were. Another example would be Germany ... historically has been very inactive, but at the moment they're going through an active phase [also] Australia ... Canada, Poland - that's partly because we have a Polish chair at the moment, a very, very good Pole at the moment ... France always, pretty much always, UK usually would be on that list, but it's not at the moment ... The Nordics are a bit more complicated. (R3-OECD)

Not surprisingly, R3 had much less to say about facilitation as a way of promoting learning. It could help, he noted, but the OECD was not in a good position to make good use of it, given the perception that European countries have of it as neoliberal and the USA often seeing it as too continental in thought. R3 was in turn rather ambivalent about the contributions that national experts can make to the learning process: 
Yes and no. I mean, as ever, as any international organization will tell you, the idea of contracting out your work to outside experts is lovely in theory and horrible in practice. They never quite deliver what you actually want ... Also it is quite difficult to find academics who have a reasonable knowledge of more than a few number of countries. (R3-OECD)

When asked about competition and exposure to the global economy, R3 also expressed ambivalence:

Would we say that globalization forces you to do something? Not quite directly; it would be much more that this is damaging to your labor market or this is very distortionary compared with other countries that you deal with, it's probably not a good idea ... but you know, I do say that, but I sometimes do these broad sweeping presentations about what's happening to social policy and, yeah, globalization makes an appearance in there. (R3-OECD)

R3 had then a number of intriguing insights into the learning process that do not fall neatly under any existing theory of learning. Moments of crises, such as the fall of the Soviet Union, offer powerful opportunities for significant learning. Then, he said, the Eastern European countries 'wanted to learn'. But crises can also prevent officials from being open to new ideas. On a more structural level, R3 felt that federal countries may be more open to learning than unitary ones given that their national governments have typically fewer responsibilities on their shoulders and thus less at stake. New governments are, in turn, often quite open to input. Finally, in areas where significant new ideas have already been put into place (such as pension), officials are likely to be too exhausted to consider additional insights.

\section{NCM}

NCM officials spoke very highly of various facilitation techniques for promoting learning among nation states. Inclusiveness and representation are especially prized in the Nordic Committee on Health and Social Affairs. Only then, officials feel, are national representatives exposed and open to each others' ideas:

We have this rule that there should always be at least three countries involved in a specific project. So that means that any given project will ... have some kind of information or learning process inherited. Also with our institutions [there is] a member from each and every country ... usually on the different working groups we also have ... people from all the countries ... Sometimes also we do have the three autonomous regions of Greenland, Faroe Islands, and the Åland Islands. (R4-NCM)

\section{R5 shared this view:}

We of course should and shall treat all countries equal, and we also know that on a five-year basis the chairmanship of the Nordic cooperation changes. So if we go in 
a kind of special cooperation mode with one country against the rest, we know that they will end up being our chairman in a few years to come, so there's kind of a check and balance.

But representation and inclusion can also have negative consequences. They can slow down progress and limit what is being shared. As R4 put it:

The Nordic cooperation is based on consensus, so we very easily end up with the smallest common denominator in any given question, so we have kind of to push the limit somewhat in order to also push this common denominator being not the absolute smallest.

NCM officials pointed to participation in the global market place as a second major factor that is conducive to learning. The Nordic countries are small with economies fully integrated at the international level. They are also reliant on an expensive but also quite successful welfare model that ensures fast retraining of the workforce, high levels of productivity, efficient labor markets, and more. Exposure to the global economy has forced the member states to evaluate carefully their approach - to entertain possibilities, to hear each others' ideas. As our interviewees put it:

Well, the premiers just met on ... Monday ... and I haven't read the press release, but I think, I know, it would state something like, that ... the whole globalization issue has been kind of the overall heading for a very large proportion of our activities ... both from the social side and from science and business and climate and whatever. (R4-NCM)

But ... the whole approach is also to look at the possibilities ... in terms of developing the Nordic welfare model. (R5-NCM)

Somewhat surprisingly, NCM officials had mixed views on the contribution of experts. R5 was especially clear about this:

We have the expert groups. We have around twelve expert groups in the social and health sector ... But I would say that our expert groups are very much living their own lives more or less. I mean, our communication with the expert group is very limited, but we use them, if we need some proposals for activities within some specific areas.

At the same time - in line with the coercion hypothesis - NCM officials noted that certain players try to influence both the amount and direction of the learning, though they said little about the extent to which those efforts bear fruit:

Norway, Sweden, and Finland ... differ a little, but they're very pro Nordic cooperation. And I would not say that Denmark is against it, but it seems to me ... that Denmark says that we have some very specific tasks that we want to be undertaken on the Nordic level and nothing else ... because some of these things are dealt with in the EU, WTO, [etc.]. (R4-NCM) 
The Danish position on cooperation, in turn, is generally supported by Iceland.

Important differences, then, set our respondents from the OMC, OECD, and NCM apart. We reflect on their perspectives in the concluding section of this article.

\section{Discussion: Learning in IGOs}

We investigated learning in three IGOs - the OMC, OECD, and NCM - in the area of social protection. Our respondents were senior IGO bureaucrats continuously involved with the learning process over long periods of time and with an eye on all the member states. Two themes in particular emerged from our research.

First, IGOs are, in fact, clearly valuable forums for learning about social protection. At the formal level, national representatives do learn about each others' policies. But the senior officials running the relevant units made clear that, consistent with organizational theories of 'decoupling', actual everyday learning also happens rather informally and concerns not policy content but 'governance' and 'epistemes': how to get things done, and how to think about problems and solutions. This is indeed what national representatives appreciate and look for the most, and where our attention should go when examining learning in IGOs. And this is certainly something that those national representatives cannot gather easily by exposure to INGOs, expert networks, or simply examining from their domestic confines what 'others' are doing.

Second, the same respondents made clear that - in line but also beyond the expectations of constructivist, coercive, facilitation-oriented, and competition-centered theories of policy learning - quite different factors promote or block learning. OMC officials stressed the importance of expert networks and facilitation techniques. They also underscored the role of open or closed mindsets in the member states. The OECD official emphasized the importance of forceful guidance and imposition, as well as the impact of crises and governmental structures. NCM officials mentioned facilitation, consensus building, and exposure to the rigors of global competition.

Our findings generate three important implications for future research. First, from a theoretical standpoint, we need more case studies to help us generalize about learning in IGOs when it comes to social policy but also beyond. Our evidence concerns three case studies in the area of social protection only. Moreover, the perspectives of our respondents, though very valuable, are limited. What, then, is happening in other IGOs? What would other stakeholders think learning is about in the OMC, OECD, and the NCM? How are the learning dynamics different in different policy areas?

Second, from a practical standpoint, we should explore in detail the possibility of 'best practice' in IGOs - again in social policy but also beyond. Here 
the intention is to identify, among the various mechanisms that help learning, those that are most efficient and effective. We also wish to know whether some mechanisms work better in some contexts and not others. Are there particular institutional practices that are actually effective regardless of setting? This would not only shed light on the learning process but also help bureaucrats improve their organizations.

Finally, when it comes to practice again, we should reflect more on the interesting split between formal structures and objectives, and what senior bureaucrats think is actually happening on the ground on a daily basis. If national representatives are above all eager to learn about governance and epistemes, can something be done to further learning in those areas? Must that learning always occur in the shadow or can it be brought to the fore, supported, and even expanded?

Our OMC interviewees told us of an Internet initiative they have launched where policy makers share ideas about governance. It is an informal and carefully moderated space. It might serve as the basis for something more promising in the future. Our OECD respondent stressed that governance in particular is often a politically sensitive subject matter. Perhaps creative ways me be devised to capture and codify successful approaches without making reference to specific countries or situations. The same may be said for matters related to epistemic questions. Our discussions with the NCM respondents reminded us that the basic tone and mission of an IGO - confrontational and competitive, for instance, versus cooperative and inclusive - can make a difference for what participants are willing to share. Our point is straightforward: IGOs and their member states might wish to focus their learning efforts more explicitly on governance issues and epistemic communities.

\section{ACKNOWLEDGEMENT}

A grant from the International Center for Business and Politics (Copenhagen Business School) allowed us to travel to Brussels and Paris to interview our OMC and OECD respondents. We are grateful to the Center for its support. We also thank all of our respondents for graciously agreeing to meet with us and share their valuable perspectives on learning.

\section{NOTES}

1. For an exception (on the OECD), see Lehtomen (2007) and Deacon and Kaasch (2008).

2. The questionnaire is available upon request.

3. For reports on social protection from 2001 on, see: http://ec.europa.eu/employment _social/spsi/strategy_reports_en.htm

4. For all JRs since 2002, see: http://ec.europa.eu/employment_social/spsi/joint_ reports_en.htm

5. For a description of the process and access to short reports, see: http://ec.europa.eu/ employment_social/spsi/peer_review_en.htm 
6. For details on indicators in social protection, see: http://ec.europa.eu/employment_ social/spsi/common_indicators_en.htm

7. For details on the OECD's official program and activities in social protection, see: http://www.oecd.org/about/0,3347,en_2649_33933_1_1_1_1_1,00.html

8. For details about the Nordic Council of Ministers for Health and Social Affairs, see http://www.norden.org/en/nordic-council-of-ministers/council-of-ministers/ council-of-ministers-for-health-and-social-affairs-mr-s

\section{REFERENCES}

Armingeon, K. and Beyeler, M. (eds) (2003) The OECD and European Welfare States. Cheltenham and Northampton: Edward Elgar.

Barnett, M. and Finnemore, M. (2004) Rules for the World: Organizations in Global Politics. Ithaca, NY: Cornell University Press.

Bennett, A. and Elman, C. (2007) 'Qualitative Research: Recent Developments in Case Study Methods', Annual Review of Political Science 9(1): 455-76.

Biegelbauer, P. (2007) 'Learning from Abroad: The Austrian Competence Centre Programme Kplus', Science and Public Policy 34(9): 606-18.

Checkel, J.T. (2005) 'International Institutions and Socialization in Europe: Introduction and Framework', International Organization 59(4): 801-26.

Christensen, R.K. (2006) 'International Nongovernmental Organizations: Globalization, Policy Learning, and the Nation-State', International Fournal of Public Administration 29(4-6): 281-303.

Deacon, B. (2007) Global Social Policy and Governance. London: SAGE.

Deacon, B. and Kaasch, A. (2008) 'The OECD's Social and Health Policy: Neo-liberal Stalking Horse or Balancer of Social and Economic Objectives?', in R. Mahon and S. McBride (eds) The OECD and Transnational Governance (pp. 226-41). Vancouver: UBC Press.

De Jong, M. and Edelenbos, J. (2007) 'An Insider's Look at Policy Transfer in Transnational Expert Networks’, European Planning Studies 15(5): 687-706.

Dobbin, F., Simmons, B. and Garrett, G. (2007) 'The Global Diffusion of Public Policies: Social Construction, Coercion, Competition, or Learning?', Annual Review of Sociology 33: 449-72.

Dolowitz, D. and Marsh, D. (1996) 'Who Learns From Whom?: A Review of the Policy Transfer Literature', Political Studies 44(2): 343-57.

Dolowitz, D. and Marsh, D. (2000) 'Learning From Abroad: The Role of Policy Transfer in Contemporary Policy-Making', Governance 13(1): 5-24.

Gerring, J. (2004) 'What Is a Case Study and What Is It Good for?', American Political Science Review 98(2): 341-54.

Gordenker, L. and Weiss, T.G. (1996) 'Pluraling Global Governance: Analytical Approaches and Dimensions', in T.G. Weiss and L. Gordenker (eds) NGOs, the UN and Global Governance (pp. 17-51). Boulder, CO: Lynne Rienner Publishers.

Grüning, T., Strünck, C. and Gilmore, A.B. (2008) 'Puffing Away?: Explaining the Politics of Tobacco Control in Germany', German Politics 17(2): 140-64.

Haas, P.M. (1992) 'Epistemic Communities and International Policy Coordination', Governance 46(1): 1-35.

Hall, P.A. (1993) 'Policy Paradigms, Social Learning, and the State: The Case of Economic Policymaking in Britain', Comparative Politics 25(3): 275-96.

Hatzopoulos, V. (2007) 'Why the Open Method of Coordination Is Bad For You: A Letter to the EU', European Law Fournal 13(3): 309-42. 
Hopper, P. (2007) Understanding Cultural Globalization. Cambridge: Polity Press.

Hough, D. (2005) 'Learning from the West: Policy Transfer and Programmatic Change in the Communist Successor Parties of Eastern and Central Europe', Fournal of Communist Studies \& Transition Politics 21(1): 1-15.

Howlett, M. and Ramesh, M. (1993) 'Patterns of Policy Instrument Choice: Policy Styles, Policy Learning and the Privatization Experience', Review of Policy Research 12(3): 3-24.

Hulme, R. (2006) 'The Role of Policy Transfer in Assessing the Impact of American Ideas on British Social Policy', Global Social Policy 6(2): 173-95.

Johnston, A.I. (2008) Social States: China in International Institutions. Princeton, NJ: Princeton University Press.

Lehtonen, M. (2007) 'Environmental Policy Integration through OECD Peer Reviews: Integrating the Economy with the Environment or the Environment with the Economy?', Environmental Politics 16(1): 15-35.

Lewis, J. (2005) 'The Janus Face of Brussels: Socialization and Everyday Decision Making in the European Union', International Organization 59: 937-71.

Mabbett, D. (2007) 'Learning by Numbers?: The Use of Indicators in the Co-ordination of Social Inclusion Policies in Europe', Fournal of European Public Policy 14(1): 78-95.

Mahon, R. and McBride, S. (eds) (2008) The OECD and Transnational Governance. Vancouver: UBC Press.

Martin, L.L. and Simmons, B.A. (1998) 'Theories and Empirical Studies of International Institutions', International Organization 52(4): 729-57.

Meissner, C.M. (2002) 'A New World Order; Explaining the Emergence of the Classical Gold Standard', NBER Working Paper No. 9233.

Meyer, J.W. and Rowan, B. (1991) 'Institutionalized Organizations: Formal Structure as Myth and Ceremony', in W.W. Powell and P.J. DiMaggio (eds) The New Institutionalism in Organizational Analysis (pp. 41-62). Chicago, IL: University of Chicago Press.

Meyer, John W. and Scott, W.R. (eds) (1983) Organizational Environments: Ritual and Rationality. Beverly Hills, CA: SAGE.

Nordic Council of Ministers (2007) What Lies Ahead for the Nordic Model? Copenhagen: Nordic Council of Ministers.

Odell, J.S. (2004) 'Case Study Methods in International Political Economy', in D.F. Sprinz and Y. Wolinsky-Nahmias (eds) Models, Numbers, and Cases: Methods for Studying International Relations (pp. 56-80). Ann Arbor: University of Michigan Press.

Oliver, M.J. and Pemberton, H. (2004) 'Learning and Change in 20th-Century British Economic Policy', Governance 17(3): 415-41.

Orenstein, M.A. (2008) Privatizing Pensions: The Transnational Campaign for Social Security Reform. Princeton, NJ: Princeton University Press.

Organization for Economic Co-operation and Development (OECD) (2003) Transforming Disability into Ability. Paris: OECD.

Paterson, W.E. and Sloan, J. (2005) 'Learning from the West: Policy Transfer and Political Parties', Fournal of Communist Studies \& Transition Politics 21(1): 33-47.

Peters, G. (1997) 'Policy Transfers between Governments: The Case of Administrative Reforms', West European Politics 20(4): 71-88.

Petersen, K. (2006) 'Constructing Nordic Welfare?: Nordic Social Political Cooperation 1919-1955', in N.F. Christiansen, K. Petersen, N. Edling and P. Haave (eds) The Nordic Model of Welfare: An Historical Reappraisal (pp. 67-99). Copenhagen: Museum Tusculanum.

Schäfer, A. (2006) 'A New Form of Governance?: Comparing the Open Method of Coordination to Multilateral Surveillance by the IMF and the OECD', Fournal of European Public Policy 13(1): 70-88. 
Shanks, C., Jacobson, H.K. and Kaplan, J.H. (1996) 'Inertia and Change in the Constellation of International Governmental Organizations, 1981-1992', International Organization 50(4): 593-627.

Sinn, H.W. and Ochel, W. (2003) 'Social Union, Convergence and Migration', Fournal of Common Market Studies 41: 869-96.

Stone, D. (1999) 'Learning Lessons and Transferring Policy across Time, Space and Disciplines', Politics 19(1): 51-9.

Stone, D. (2002) 'Non-Governmental Policy Transfer: The Strategies of Independent Policy Institutes', Governance 13(1): 45-70.

Stone, D. (2004) 'Transfer Agents and Global Networks in the "Transnationalization" of Policy', Journal of European Public Policy 11(3): 545-66.

Studlar, D.T. (2006) 'Tobacco Control Policy Instruments in a Shrinking World: How Much Policy Learning?', International fournal of Public Administration 29(4-6): 367-96.

Tomlinson, J. (1999) Globalization and Culture. Chicago, IL: University of Chicago Press.

Vetterlein, A. (2007) 'Economic Growth, Poverty Reduction and the Role of Social Policies: The Evolution of the World Bank's Social Development Approach', Global Governance 13(4): 513-34.

Woods, N. (2006) The Globalizers: The IMF, the World Bank, and their Borrowers. Ithaca, NY: Cornell University Press.

Yeates, N. (ed) (2008) Understanding Global Social Policy. Bristol: Policy Press.

Zeitlin, J. and Pochet, P. (eds) (2005) The Open Method of Co-ordination in Action: The European Employment and Social Inclusion Strategies. Brussels: Peter Lang.

RÉS UMÉ

\section{Apprentissage dans les Organismes Gouvernementaux Internationaux: Le Cas de la Protection Sociale}

Il y a beaucoup de recherche aux responsables des politiques à l'échelon national s'inspirer de l'expérience d'autres pays. Beaucoup des études examinent les processus et les personnes qui travaillent au niveau international. Dans cette égard, relativement peu d'attention est accordée pour organismes gouvernementaux internationaux (OGI), sauf pour l' 'Open Method of Coordination' de l'EU. Dans cette article, on fait une étdue comparative pour l'apprentissage dans trois OGIs: l'EU, l'OECD, et le Conseil de Ministres nordique. Notre domaine d'action est la protection sociale. On étudie les connaissances acquises, et les facteurs qui favorisent ou bloquent l'apprentissage. Notre méthodologie implique une analyse de la conception formelle de ces OGIs et entrevues face à face avec des hauts fonctionnaires de chaque organisation. Premièrement, on observe que l'apprentissage le plus important pour les OGIs concerne les sujets qui sont indépendant des ordres du jour formels - le gouvernement et issues de l'epistémologie partout. Deuxiémement, nous voyons que les éléments très différents favorisent ou bloquent l'apprentissage pour des organismes différents. Les implications de ces résultats pour la théorie et la pratique sont discutées. 
RESUMEN

\section{El Aprendizaje en las Organizaciones Gubernamentales Internacionales: El Caso de la Protección Social}

Existen muchas investigaciones sobre la manera en que los encargados de la política nacional aprenden del exterior. La mayoría de estas investigaciones se centran en los procesos y los protagonistas que trabajan a nivel internacional. En ese hilo, poca atención ha sido prestado a las organizaciones gubernamentales internacionales (las OGI), aparte del 'método abierto de coordinación' de la UE. En el presente documento, se realiza un estudio comparativo sobre el aprendizaje en tres OGI: la UE, la OCDE y el Consejo de Ministros Nórdico. Nuestra área de política es la protección social. Se examina lo que está siendo aprendido, y los factores que promueven o impiden el aprendizaje. Nuestra metodología supone un análisis del diseño formal de esas OGI e incluye entrevistas caraa-cara con burócratas de alta jerarquía en cada organización. Se observa, en primer lugar, que el aprendizaje más importante en las OGI concierne los asuntos que no forman parte de las agendas formales - la gobernabilidad y los asuntos epistémicos sobre todo. En segundo lugar se observa que son muy distintos los factores que promueven o impiden el aprendizaje en diferentes organizaciones. Se reflexiona sobre las consecuencias de estas conclusiones tanto para la teoría como para la práctica.

\section{BIOGRAPHICAL NOTES}

FRANCESCO DUINA holds a PhD in Sociology from Harvard University and is Associate Professor of Sociology at Bates College (USA) and Visiting Professor at the Copenhagen Business School (Denmark). He is the author of The Social Construction of Free Trade: The European Union, NAFTA, and MERCOSUR (Princeton University Press, 2006), Harmonizing Europe: Nation States within the Common Market (SUNY Press, 1999), and articles in journals such as Economy and Society, Review of International Political Economy, and Fournal of European Public Policy. Please address correspondence to: Francesco Duina, Department of Sociology, 263 Pettengill Hall, Bates College, Lewiston ME 04240, USA. [email: fduina@bates.edu]

Peter nedergaard holds a MSc in Political Science and a PhD in Political Science from the University of Aarhus. He was appointed Professor at the University of Copenhagen (Denmark) in 2008. Before this he was Professor at Copenhagen Business School (Denmark). He has published widely in international journals such as the Fournal of Common Market Studies, Fournal of European Integration, Public Choice, Scandinavian Political Studies, Public Management Review, and Cooperation and Conflict. Please address correspondence to: Peter Nedergaard, Centre of European Politics, Øster Farimagsgade 5, 1353 København K., Denmark. [email: pne@ifs.ku.dk] 